KERN, R. A. Een episode uit het La Galigo epos. $B T L V, 117,1961,363-383$.

Krupa, V. and G. Altmann. Semantic analysis of the system of personal pronouns in Indonesian language. $A O, 29,1961,620-625$.

OstrovskII, V. A. K periodizatsii sovremennoi INdoneziiskoi literatury. Problemy Vostokovedeniia, 6, 1959, 57-67.

Pijper, G. F. Professor Dr. Pangeran Ario Hoesein Djajadiningrat, 8 December 1886-12 November 1960 . BTLV, 117, 1961, 401-409.

REsink, G. J. Jozef Korzeniowski's voornaamste lectuur betreffende Indonesië. $B T L V, 117,1961$, 209-237.

Verguin, J. De la syntaxe du prédicat en indonésien. Travaux de l'Institute de Linguistique, 4, 1959, 49-56.

Verguin, J. Expression du procès en tontemboan. $B S L P, 55,1960,270-276$.

\section{MALAYA including SINGAPORE, SARAWAK, BRUNEI and NORTH BORNEO}

\section{Periodicals}

The Commerce. Journal of the Commerce Society. Singapore, Nanyang University, College of Commerce. (In English and Chinese.) 1961, v. 1,4 .

Directory of the State of Singapore including trade index and biograpbical section. London, Diplomatic Press. 1960-61.

The Education journal. Singapore, University of Malaya, Education Society. 1961, v. 2.

Federation of Malaya yearbook. Kuala Lumpur, Straits Times Press. 1961.

Journal of tropical geograpby. Singapore and Kuala Lumpur, University of Malaya, Department of Geography. 1961, v. 15.

Leaders of Malaya and wbo's who. 3rd edition. Kuala Lumpur, Khee Meng Press. 1959-60.

Malaya (Federation). Department of StatisTics. Montbly statistical bulletin. Kuala Lumpur. 1961, Jan.-Dec.

Malaya (Federation). Embassy, United States. Nerws bulletin. Washington, D. C. 1961, nos. 56-75.

Malaya (Federation). Ministry of Culture. Weekly digest of Malay, Cbinese and Tamil press. Singapore. 1961, nos. 1-41 (ceased publication.)

Malaya. Journal of the British Association of Malaya. London. 1961, Jan.-Dec.

Malaya in bistory. The magazine of the Malayan Historical Society. Kuala Lumpur, Malayan Historical Society. 1961, v. 6, 2; v. 7, 1.

Malayan bulletin. London, British Association of Malaya. 1961, v. 15, 167-178.

Malayan economic review. Journal of the $\mathrm{Ma}$ layan Economic Society. Singapore, Malaya Publishing House Ltd. 1961, v. 6, 1-2.

Malayan law journal. Singapore, G. H. Kiat Co., Ltd. 1961, v. 27.
Malayan library journal (Persekutuan Tanab Melayu). Kuala Lumpur, Persatuan Perpustakaan. 1960-61, v. 1, 1-4; v. 2, 1.

Sabah Society, Jesselton, N. Borneo. Journal. 1961 , no. 1.

Sarawak by the week. Kuching, Sarawak Information Service. 1961, nos. 1-52.

Sarawak museum journal. Kuching, Sarawak Museum. 1961, v. 10, new series, 17-18.

Seed. Singapore, Malaysian Sociological Research Institute. 1961, v. 1, 1-6.

Singapore. State of Singapore annual report. 1959 (published 1961).

Singapore trade. Singapore, Straits Times Press (Malaya) Ltd. in cooperation with the Division of Commerce and Industry of the Ministry of Finance. 1961, Jan.-Dec.

Straits times annual. Singapore, Straits Times Press (Malaya) Ltd. 1961.

Straits times Malayan trade digest. Singapore and Kuala Lumpur, the Straits Times Press (Malaya) Ltd. 1961, Jan.-Dec.

Three-montbly economic review: Federation of Malaya, Singapore, British Borneo Territories. London, the Economist Intelligence Unit, Ltd. 1961, nos. 33-36 (annual supplement, June 1961).

Tin news. Washington, D. C., Malayan Tin Bureau. 1961, Jan.-Dec.

University of Malaya law review. Singapore. 1961, v. 3, July, Dec.

\section{General}

\section{Books}

BITsCh, JøRGen. Ulu: the world's end. Translated from the Danish by Reginald Spink. London, Allen and Unwin [1961]. 142 p. plates (part col.). (Translation of Ulu: verdens ende.)

DAs, S. A. A handbook of Malayan studies, including Singapore, for secondary schools. Based closely on the syllabus on Malayan studies issued by the Ministry of Education, Federation of Malaya. Singapore, Malaya Pub. House [1961?] 150 p. illus., maps.

Malaya (Federation) Dept. OF INFormation. Federation of Malaya: Progress in pictures. [A photo story of some of the more notable progress of the Federation of Malaya under the new nation's first five-year development plan, 19561960. Kuala Lumpur, Federation of Malaya Information Services, 1960]. [70] p. illus., map.

Moran, Jack William Grace. The camp across the river; further recollections of an officer in the Malayan police force. London, P. Davies [1961] $191 \mathrm{p}$.

Roff, William R. Guide to Malay periodicals, 1876-1941, with details of known holdings in Malaya. Singapore, Published for the Dept. of History in the University of Malaya in Kuala Lumpur by Eastern Universities Press, 1961. 
46 p. (Papers on Southeast Asian subjects, no. 4)

Sutrer, John Orvat. Scientific facilities and information services of the Federation of Malaya and State of Singapore. Honolulu, Published for the National Science Foundation by the Pacific Scientific Information Center, 1961. 43 p. diagrs., maps.

\section{Articles}

LeECH, W. S. C. The Federation of Malaya. JRCAS, 48, 1961, 173-180.

\section{History}

\section{Books}

Aeby, Muara. Hari Kamahkotaan. Coronation [of the Sultan of Johore.] [Singapore? Diterbitkan oleh Samudra, Printed at Weng Printers, by Hiap Seng Press, 1960l. 50 p. illus.

Bredin, Alexander Edward Craven. The happy warriors. Gillingham, Dorset, England, Blackmore Press, 1961.356 p. plates.

Chaphekar, Shankarrao Gangadharrao. A brief study of the Malayan campaign, 1941-42. 2d and rev. ed. [Poona, S. V. Damle] 1960. 121 p. maps.

Cowan, Charles Donald. Nineteenth-century Malaya; the origins of British political control. London, New York, Oxford University Press, 1961. 286 p. maps (part fold.) (London oriental series, v. 11)

Wheatley, Paul. The goldern Khersonese; studies in the historical geography of the Malay Peninsula before A.D. 1500. Oxford University Press, 1961. xxxiii, 388 p. illus., maps.

\section{Articles}

Babin, V. Una tappa nell'evolutione dell'Impero britannico: la creatione dello stato di Singapore. Com. Internaz., 16, 1961, 303-323.

Bassetr, D. K. The surrender of Dutch Malacca, 1795. BTLV, 117, 1961, 344-358.

Bennetr, H. G. The conquest of Malaya. [Review article.] JSAH, 2, 3, 1961, 91-100.

Harrison, C. R. The last of the Creepers. Memoirs of a Malayan rubber planter 1907-1917. Malaya in History, 7, 1, 1961, 18-27.

IRIA, A. Elementos de estudo acerca da possível contribuição portugesa para a organização do Museu Histórico de Malaca. [Cont. from 6, 1960, 57-120.] Studia, 7, 1961, 107-149.

Josseuin De Jong, P. E. De. Who's Who in the Malay Annals. JRASMB, 34, 2, 1961, 1-89.

Josseun, De Jong, P. E. De and H. L. A. Van WIJK. The Malacca Sultanate (an account from a hitherto untranslated Portuguese source). JSAH, 1, 2, 1960, 20-29.

LAMB, AlASTAIR. Miscellaneous papers on early Hindu and Buddhist settlement in Northern
Malaya and Southern Thailand. FMJ, 6, 1961, $1-90, \mathrm{i}-1$.

MAClNTYRE, D. Britain's intervention in Malaya: the origin of Lord Kimberley's instructions to Sir Andrew Clarke in 1873. JSAH, 2, 3, 1961, 47-69.

Pengeran Anum, Engru. A conqueror's correspondence a century ago. Malaya in History, $6,2,1961,9-19$.

Puvanarajah, T. and R. Suntharalingam. The Acheh treaty of 1819. JSAH, 2, 3, 1961, 36-46.

SмIтн, W. H. C. The Portugese in Malaca during the Dutch period. Studia, 7, 1961, 87-106. Tregonning, Kennedy Gordon. The history of Malaya: a new interpretation. $E H, 1,13,1961$, 13-18.

Yahya Bin Yusof, НAJ. The legend of Meriam Keramat. Malaya in History, 7, 1, 1961, 28-29.

\section{Archaeology}

\section{Books}

Lamb, Alastair. Chandi Bukit Batu Pahat; three additional notes. Singapore, Published for the Dept. of History in the University of Malaya in Kuala Lumpur by Eastern Universities Press, 1961. 25 p. illus. (Papers on Southeast Asian subjects, no. 5)

Matthews, John. A check-list of Hoabinhian sites excavated in Malaya, 1860-1939. Singapore, published for the Department of History in the University of Malaya in Kuala Lumpur by Eastern Universities Press, 1961. x, 59 p. map, table. (Papers on Southeast Asian subjects, no. 3)

\section{Articles}

Lamb, Axastair. Pengkalan Bujang, an ancient port in Kedah. Malaya in History, 7, 1, 1961, 12-17.

LAMB, Alastarr. Report on the excavation and reconstruction of Chandi Bukit Batu Pahat, Central Kedah. $F M J, 5,1960,1-108,73$ pls.

Loewenstern, J. An "Ordos" bronze knife from prehistoric Malaya. Antbropos, 56, 1961, 936937.

McHugr, J. N. The dragon of Chini and recent discoveries under the Lake. Malaya in History, 6, 2, 1961, 3-8.

Nong Jiwa, Tunku. Gua Cherita-the cave with a legend. Malaya in History, 6, 2, 1961, 20-21.

Peacock, B. A. V. A short description of Malayan prehistoric pottery. $A P, 3,1959,121-$ 156.

Pengiran Anum, Engku. How the Trengganu Stone was found. Malaya in History, 7,1 , 1961, 30-33.

\section{Geography, Description and travel Books}

Alusson, Cyrit. In the shadow of Kinabalu. 
London, R. Hale [1961] 191 p. illus., map.

Birsch, Jörgen. Tamapaya, Paradies am Ende der Welt. Berlin, Ullstein [1960]. 230 p. col. plates, map.

InghaM, Frank Tintey. The geology and mineral resources of the Kinta Valley, Perak, by F. T. Ingham and E. F. Bradford. [Kuala Lumpur, B. T. Fudge, Govt. printer, 1960]. xxi, 347 p. illus., maps, diagrs., tables. (Federation of Malaya. Geological Survey. District memoir 9)

Malayan Nature Society. Nature conservation in Western Malaysia, 1961. Edited by J. WyaatSmith and P. R. Wycherley. Kuala Lumpur, the Malayan Nature Society, 1961. viii, 260 p. illus., maps.

Smythies, Bertram Evelyn. The birds of Borneo. With special chapters by Tom Harrisson, Lord Medway, and J. D. Freeman. With 50 plates in colour by A. M. Hughes and 49 photographic plates by Loke Wan Tho [and others] Edinburgh, Oliver and Boyd [1960] xvi, 562 p. illus., plates (part col.) fold. col. map.

\section{Articles}

Carter, J. Mangrove succession and coastal change in south-west Malaya. Trans. Papers I. Brit. G., 26, 1959, 79-88.

Nossin, J. J. Relief and coastal development in North-Eastern Johore (Malaya). JTG, 15, 1961, 27-38.

Verstappen, Herman Theodor. Some observations on karst development in the Malay Archipelago. JTG, 14, 1960, 1-10.

WARD, MARION WyBourn. Recent changes in the economic geography of Malaya. Geography, $45,1960,294-297$.

\section{Economics}

\section{Books}

Bastin, John Sturgus. The changing balance of the early Southeast Asian pepper trade. University of Malaya in Kuala Lumpur, Department of History. 67 p. maps. (Papers on Southeast Asian subjects, no. 1)

Board of Commissioners of Currency (Malaya, Singapore, Sarawak, North Borneo and BruNEI). Report of the Commissioners of Currency, Malaya and British Borneo, 1959, by Goh Keng Swee, chairman. Singapore, Nanyang Printers, 1960. 24 p.

Far Eastern Features Service, Singapore. Report on finance, commerce and industry, Federation of Malaya, 1960, by Paul Markandan, editor, Far Eastern Features Service. Singapore, 1960. iv, 125 p. illus.

First National City Bank of New York. Federation of Malaya; a report on business and trade. New York, 1959.13 p. illus.

International Labor Office. Report to the
Government of Malaya on the establishment of a printing training centre. Geneva, 1960. ii, 50 p. illus. "ILO/TAP/Malaya/R.11."

Malaya (Federation) Special Advisory Committee on Cost of Living Indices. Report on proposals for new retail price indices and statement of policy by the Federation Government. [Kuala Lumpur, 1959?] 11 p. tables.

U. S. Bureau of Foreign Commerce (1953- ) Far EAstern Division. Economic developments in the Federation of Malaya, 1960. [Prepared by Mirza T. Baig] Washington, U. S. Govt. Print. Off., 1961. 4 p. (World Trade Information Service. Economic reports, pt. 1, no. 619)

\section{Articles}

Courtenay, P. P. International tin restriction and its effects on the Malayan tin mining industry. Geography, 46, 1961, 223-231.

Fisk, E. K. Productivity and income from rubber in an established Malay reservation. $M E R$, 6, 1, 1961, 13-22.

LiM, Chong-Yan. The Malayan rubber replanting taxes. $M E R, 6,2,1961,43-52$.

Mchale, Thomas R. The Malayan economy and stereo-regular rubbers. Asian Survey, 1, 4, 1961, 25-28.

Moy-Thomas, A. H. Economic Development under the Second Rajah (1870-1917). SMJ, $10,17-18,1961,50-58$.

OoI Jin-BeE. The rubber industry of the Federation of Malaya. JTG, 15, 1961, 46-65.

Tan, SiEw Sin. Protection of Malaya's industries. $A R, 57,1961,49-54$.

\section{Sociology and Anthropology \\ Books}

Winstedt, Sir Richard Olof. The Malay magician, being Shaman, Saiva and Sufi. Rev, and and enl., with a Malay appendix. London, Routledge and K. Paul [1961] 180 p. illus.

\section{Articles}

Burridge, K. O. L. Kuda Kepang in Batu Pahat, Johore. Man, 61, 1961, 33-36.

Cheng, U-Wen. Opium in the Straits Settlements, 1867-1910. JSAH, 2, 1961, 52-75.

FATIMI, S. Q. In quest of Kalah. JSAH, 1, 2, 1960, 62-101.

Jorns, A. H. The role of Sufism in the spread of Islam to Malaya and Indonesia. JPHS, 9, 1961, 143-161.

SandHu, Kernial Singh. The population of Malaya; some changes in the pattern of distribution between 1947 and 1957. JTG, 15, 1961, 82-96.

Sendut, Hamzah. Problems of rural-urban migration in Malaya. $C D B, 12,1961,86-91$.

Sendut, Hamzah. Rasah-a resettlement village in Malaya. Asian Survey, 1, 9, 1961, 21-26. 
Sheridan, L. A. Malay marriages. Patna Law College Studies in Law, 1961, 492-508.

Wong, Lin-Ken and C. S. Wong. Secret societies in Malaya. (a review article). JSAH, $1,1,1960,97-114$.

\section{Political science}

\section{Books}

AdkINs, E. H., JR. The national identity card program: the Federation of Malaya, a research report. Saigon, Michigan State University Viet Nam Advisory Group, October, 1961. iv, 109 p. illus.

Kamil, Dato' Nik Ahmed. The Federation of Malaya's role in world Affairs. [Boston, Mass., 1959] $16 \mathrm{l}$.

Moore, Daniel Eldredge. The United Malays National Organization and the 1959 Malayan elections; a study of a political party in action in a newly independent society. [Berkeley, 1960] Microfilm copy (positive) of typescript. Thesis-University of California.

\section{Articles}

Grant, Bruce. A Country called Malaysia. The Reporter, 25, 10, 1961, 41-42.

Png, Poh Seng. The Kuomintang in Malaya, 1912-1941. JSAH, 2, 1961, 1-32.

Purcell, Victor. Fédération de Malaisie et Singapour (Traduction.) Civilisations, 11, 1961, 345-350.

Purcell, Victor. Notes sur la fédération de Malaisie et Singapour. (Traduction.) Civilisations, $11,1961,220-227$.

Singhal, D. P. Greater Malaysia and India. $M R$, 110, Dec. 1961, 437-442.

Singhal, D. P. The United States of Malaysia. Asian Survey, 1, 8, 1961, 16-22.

Soenarno, Radin. Malay nationalism, 1900-1945. JSAH, 1, 1, 1960, 1-28.

Tilman, Robert $O$. Public service commissions in the Federation of Malaya. JAS, 20, 2, 1961, 181-196.

\section{Law and constitution}

\section{Books}

Malaya (Federation) Constitution. The Federation of Malaya Constitution: text, annotations, and commentary by L. A. Sheridan. Singapore, University of Malaya law review, 1961. $180 \mathrm{p}$. A revised version of a work published in instalments in the University of Malaya law review in July and December 1959 and July and December 1960, now showing the law as at 31st December 1960.

Rajasooria, Reginald Paul Selvanasan, comp. Three decades of Malayan trials [Kuala Lumpur? 1960] 145 p. illus.

ShERIDAN, Lionel Astor, ed. Malaya and Singapore, the Borneo territories; the development of their laws and constitutions. Edited by $\mathbf{L}$. A. Sheridan with specialist contributors. London, Stevens, 1961. xxi, 510 p. illus., fold. maps. (The British Commonwealth: the development of its laws and constitution, v. 9)

\section{Articles}

ChuA, B. L. Land registration in Singapore and the Federation of Malaya. UMLR, 1, 1959, 318-330.

Nallal, B. A. Malayan legal bibliography. Majallab Perpustakaan Singapura, 1, 1961, 5575.

Tan, Chor-Yong. J, Habeas corpus in Singapore. $U M L R, 2,1960,323-334$.

\section{Education}

\section{Books}

Malaya (Federation) Education Review ComMITTEE. Report, 1960. [Kuala Lumpur?] Govt. Press, 1960. x, 98 p. tables.

\section{Articles}

Comber, Leon. Chinese education-a perennial Malayan problem. Asian Survey, 1, 8, 1961, 30-35.

DunhILL, J. W. The education of a teacher in Malaya. Journal of Education (Hong Kong), $19,1961,27-34$.

Mason, Frederick. Teacher training in Malaya and Singapore 1950-1960. Journal of Education (Hong Kong), 19, 1961, 11-17.

Sreenivasan, B. R. University education in Singapore. The Education Journal, 2, 1961, 1-5.

Williams, R. Malayan teachers' colleges. Journal of Education (Hong Kong), 19, 1961, 3549.

\section{Arts, Language and Literature}

\section{Books}

Carey, Iskandar. Tengleq kui serok; a study of the Temiar language, with an ethnographical summary. Kuala Lumpur, Dewan Bahasa dan Pustaka, Kementerian Pelejaran, Persekutuan Tanah Melayu, 1961. 195 p. illus.

Hussein Bin Ati, Syed. Malay as the national language. Kuala Lumpur, Dewan Bahasa dan Pustaka, Kementerian Pelajaran, Persequtuan Tanah Melayu, 1959. 12, 12 p. (DBP booklet no. 1)

Raml, C. M. Progressive Malay. Penang, Grand Publishers, 1959. iv, $84 \mathrm{p}$,

\section{Articles}

KöpKe, W. Das Malaiische im Malaiischen Bund in seiner Entwicklung zur modernen Nationalsprache. NGNVO, 87, 1960, 32-40.

LAMB, Alastair. A model of the temple on the 
River of Cut Stone. Malaya in History, 6, 2, 1961, 34-36.

Solheim II, Wilherm G., Barbara Harrison and Lindsey Wall. Niah 'Three Colour Ware' and Related Prehistoric Pottery. SMJ, 10, 1718, 1961, 227-237.

URQUHART, I. A. N. Vocabulary Comparisons, 1911-1961. SMJ, 10, 17-18, 1961, 120-124.

Winstedt, Sir Richard Olof. A history of classical Malay literature. Revised edition. (Monographs on Malay Subjects no. 5.) JRASMB, 31, 3, 1958, 1-261 (published 1961).

Winstedt, Sir Richard Olof. Malay literature. $A R$, 57, 1961, 201-211.

\section{Singapore \\ Books}

International Labor Office. Report to the Government of Singapore on a proposed social security scheme. Geneva, I. L. O., 1959. $110 \mathrm{p}$.

Singapore. Ministry of Finance. State of Singapore development plan, 1961-1964. [Singapore, 1961] vii, 134 p. fold. maps, fold. tables.

Singapore. Prisons Inquiry Commission. Report, 1960. Singapore, Printed by L. K. Heng, acting Govt. printer, 1951. viii, 186 p. illus., fold. maps, diagrs., tables.

TsujI, Masanobu. Singapore, the Japanese version. Translated by Margaret E. Lake. Edited by $\mathrm{H}$. V. Rowe, with an introd. by $\mathrm{H}$. Gordon Bennett. Sydney, R. Smith [1960] 358 p. illus.

U. S. Trade Mission to Singapore. Report. Washington, U. S. Dept. of Commerce, Bureau of Foreign Commerce, Trade Missions Division [1961] $9 \mathrm{p}$.

\section{Articles}

Anuar, Hedwig. New Singapore National Library building. Malayan Lib. J., 1, 2, 1961, 1720.

Brown, B. Administrative internment in Singapore. JICJ, 3, 1, 1961, 126-134.

Gigon, Fernand. Singapore. Sentinelle del'Asie. Connaissance du monde, 22, Sept. 1960, 49-54.

Harron, Leonard Mongague. Six years in Singapore. Link, London University, University College School of Librarianship and Archives. 95, Sept. 1961, 4-8.

Josey, Alex. The Struggle for Singapore. FEER, $34,5,1961,263-265$.

\section{Sarawak, Brunei and North Borneo}

\section{General}

\section{Books}

Cotter, Conrad Patrick. Reading list of English language materials in the social sciences on
British Borneo, with critical annotation. [Honolulu, 1960] vii, 881.

Forrester-Wood, W. R. The stamps and postal history of Sarawak. Sarawak Specialist Society, 1959. 576 p. illus.

International Labor Office. Report to the Government of North Borneo on the development of co-operatives. Geneva, I. L. O. 1960. ii, $28 \mathrm{p}$.

INTERnational Labor Office. Report to the Government of Sarawak on the development of co-operatives. Geneva, I. L. O., 1961. 29 p.

Mullen, Vernon. The story of Sarawak. Maps and charts drawn by J. A. Kuek. Kuala Lumpur, Oxford University Press, 1960.88 p. illus.

Sarawak. Information Service. A guide to education in Sarawak. [Kuala Belait, Brunei Press] 1961. 55 p. illus. (part. fold.)

Soctety for the Propagation of the Gospel in Foreign Parts, London. Four nurses in Borneo. London [1961] 12 p. illus.

\section{Articles}

Buck, W. S. B. Brookes in Exile (1914 ). $S M J, 10,17-18,1961,59-81$.

Harrisson, Tom. Sarawak in the whirlpool of South East Asia. GM, 31, 1958-59, 378-385.

LEE, Y. L. Historical aspects of settlement in British Borneo. PV, 2, 1961, 187-212.

Weeks, J. Batu Lintang Training College [Sarawak]. Journal of Education (Hong Kong), 19, 1961, 67-71.

\section{Geography, Description and Travel Books}

Brunei, Pejabat Penerangan. Brunei in pictures. Gambar gambar peristiwa di-Brunei. Brunei, Light Press, 1961? 44 p. illus.

LIECHTI, P. The geology of Sarawak, Brunei and the western part of North Borneo. Compiled from work of the Royal Dutch Shell Group of companies on the British Territories in Borneo and from various published accounts by $P$. Liechti, in association with $F$. W. Roe and N. S. Haile. Kuching, Govt. Print. Off., 1960. 2 v. illus., plates, maps. (Geological Survey Department, British Territories in Borneo. Bulletin 3)

Wolfenden, E. B. The geology and mineral resources of the lower Rajang $V$ alley and adjoining area, Sarawak. Kuching, Sarawak, Government Printing Office, 1960. xiii, 167 p. illus. maps (part fold,, 1 in pocket). (Geological Survey Department, British Territories in Borneo. Memoir, 11.)

\section{Articles}

Donnelly, T. Walking in Sarawak. Oversea Ed., 33, 1961, 116-123.

Harrisson, Tom with Stephen Wan Ullok. A Sarawak Kenyah Journey Through Death. $S M J, 10,17-18,1961,191-213$. 
LEE, Y. L. Land settlement for agriculture in North Borneo. TESG, 52, 1961, 184-191.

LEE, Y. L. Some factors in the development and planning of land use in British Borneo. JTG, $15,1961,66-81$.

\section{Sociology and Anthropology}

\section{Books}

Stöhr, Waldemar. Das Totenritual der Dajak. Köln, E. J. Brill, 1959. xi, 245 p. illus., map. (Ethnologica, Neue Folge, Bd. 1.)

\section{Articles}

Freeman, J. D. Iban augury. BTLV, 117, 1961, 141-167.

Hewirt, John. The First Land Dayaks. $S M J$ $10,17-18,1961,112-117$.

Koblenzer, P. J. and N. H. Carrier. The fertility, mortality and nuptiality of the Rungus Dusun. Population Studies, 13, Mar. 1960, 266277.

Newingron, P. C. B. Melanau memories. SMJ, 10, 17-18, 1961, 103-107.

Prazzini, Guy. Fête chez les Dayak à Bornéo, Une tribu de coupiens de tête. Connaissance $d u$ monde, 20, July 1960, 30-40.

Sandin, Benedict. Gawai Antu: Sea Dayak Feast of the Departed Spirits. SMJ, 10, 17-18, 1961, 170-190.

WARD, A. B. Some Sea Dayak Customs and Fines, 1909-15. SMJ, 10, 17-18, 1961, 82-102.

Williams, T. R. Ethno-historical relationships and patterns of customary behavior among North Borneo native peoples. [Synopsis in German.] Sociologus, 11, 1961, 51-63.

\section{Arts, Language and Literature}

\section{Articles}

Howert, W. Supplement to Howell and Bailey's "Sea Dyak Dictionary." SMJ, 10, 17-18, 1961, 127-169.

Atman, J. H. Arts and crafts in North Borneo. Oversea Ed., 33, 1961, 62-68.

\section{VIETNAM, CAMBODIA and LAOS}

\section{Periodicals}

Banque Nationale du Cambodge. Bulletin Mensuel. Phnom-penh. 1961, 7th yr., nos. 1-12.

Les cabiers du Sangkum, revue periodique des realisations du Sangkum (Commuauté socialiste populaire). Royaume de Cambodge, le Ministere de l'Information. 1961, nos. 6-12.

Cambodge d'aujourd'bui, revue mensuelle. Phnom-penh, le Ministere de l'Information. 1961, v. 4, 1-2 (and three special numbers: May-Aug., Sept.-Oct., Nov.-Dec.).

Cambodia. Embassy, U. S. Cambodia news, an infornation bulletin. Washington, D. C. 1961, v. 4, 1-19.

Réalités cambodgiennes. Phnom-penh. 1961, 6th yr., 243-288.

Societé des Études Indochinoises, Saigon. Bulletin. 1961, new series, v. 36, 1-4.

United States Operations Mission to Vietnam. Annual report. 1961, v. 6.

United States Operations Mission to Vietnam. Program Office, Research and Statistics Section. Anmual statistical bulletin. 1961 (in preparation).

United States Operations Mission to Vietnam. Program Office, Research and Statistics SecTION. Montbly statistical bulletin. 1961, nos. 1-8.

VietNam. Embassy, France. Bulletin du Viet Nam. Paris. 1961, 11th yr., new series, nos. 212-220.

Vietnam. Embassy, United States. Press and Information OfFice. Nerws from Viet-nam. Washington, D. C. 1961, v. 7, 1-11.

Viet-nam. Hanoi. (English edition.) 1961, nos. 1(39)-12(51).

Vietnam advances. Published in English, French, and Esperanto. Hanoi, Tien Bo Printing Works. 1961, 6th yr., nos. 3-8.

Viet-nam youth. Published in English and French. Hanoi, Vietnam Youth Federation and Vietnam National Union of Students. 1961 , nos. 58-63.

\section{General}

\section{Books}

Bhandari, S. K. Viet-Nam today. New Delhi, National Publicatitons Bureau, 1961. 112 p. illus.

Democratic Repubuic of Viet Nam. Hanoi. Foreign Languages Pub. House, 1960. 159 p. illus., fold. col. map.

Democratic Republic of Viet Nam, 1945-1960; impressions of foreigners. Hanoi, Foreign Languages Pub. House, 1960. 90 p. illus.

LE XV• [i.e. Dix-cinquième] anniversaire de la République démocratique du Viet Nam, 19451960. Hanoi, Editions en langues étrangères, $1961.136 \mathrm{p}$.

Fridland, Vladimir Markovich. Priroda Severnogo V'etnama. Moskva, Izd-vo Akademii nauk SSSR, 1961.173 p. illus.

Halpers, Joel Martin, comp. An annotated bibliography on the peoples of Laos and northern Thailand; selected sources in English, French and Japanese published since 1945. Los Angeles, Dept. of Anthropology, University of California, 1961. 6 leaves.

McKinstry, John. Bibliography of Laos and ethnically related areas. Los Angeles, University of California, Dept. of Anthropology [1961] 91 1. (Laos Project. Paper no. 22)

Nguxen-Khac-Kham. Introduction to Vietnamese culture. Saigon, Dept. of National Education, 1961.32 p. illus. 